n. ${ }^{\circ} 1$

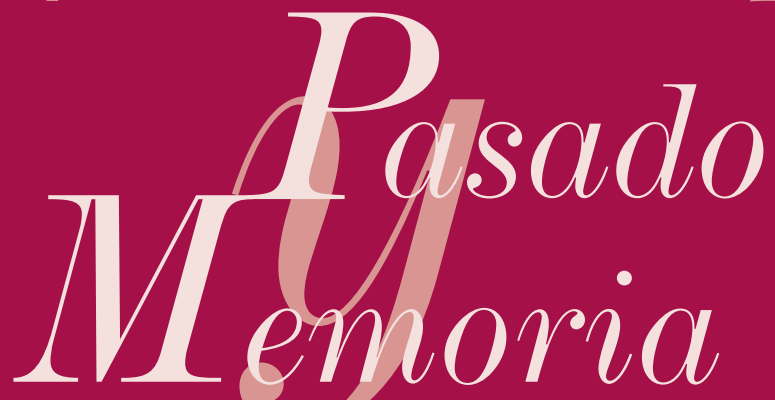

Revista de Historia Contemporánea

Instituciones y sociedad en el franquismo

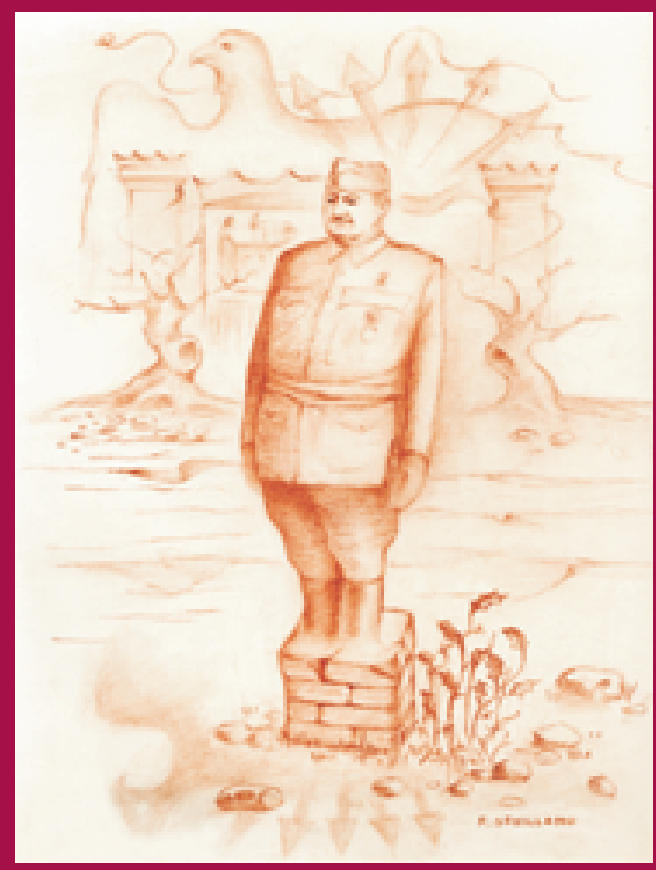




\section{Dirección: Glicerio Sánchez Recio}

Secretaría: Francisco Sevillano Calero

Consejo de redacción: Salvador Forner Muñoz, Rosa Ana Gutiérrez Lloret, Emilio La Parra López, Roque Moreno Fonseret, Mónica Moreno Seco, José Miguel Santacreu Soler, Rafael Zurita Aldeguer

Consejo asesor:
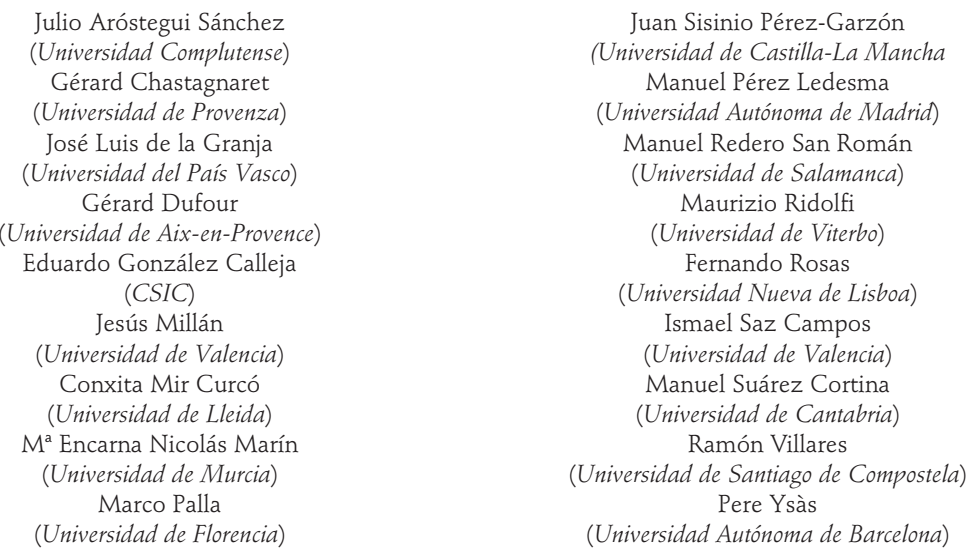

Coordinación del monográfico: Glicerio Sánchez Recio

Ilustración de la portada: El despropósito, por Francisco Sevillano Bonillo

\begin{tabular}{|c|c|c|c|}
\hline Edita: & $\begin{array}{l}\text { Departamento de Humanidades Contemporáneas } \\
\text { Área de Historia Contemporánea } \\
\text { Facultad de Filosofía y Letras } \\
\text { Universidad de Alicante } \\
\text { Apartado Postal } 99 \\
03080 \text { Alicante }\end{array}$ & Distribución: & $\begin{array}{l}\text { Publicaciones } \\
\text { Universidad de Alicante } \\
\text { Apartado Postal } 99 \\
03080 \text { Alicante }\end{array}$ \\
\hline
\end{tabular}

Composición: Espagrafic

Impresión: INGRA Impresores

Depósito legal: A-293-2002

ISSN: 1579-3311

Reservados todos los derechos. No se permite reproducir, almacenar en sistemas de recuperación de la información ni transmitir alguna parte de esta publicación, cualquiera que sea el medio empleado -electrónico, mecánico, fotocopia, grabación, etc.-, sin el permiso previo de los titulares de los derechos de la propiedad intelectual.

\section{Estos créditos pertenecen a la edición impresa de la obra}

Edición electrónica:

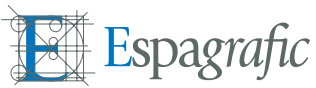




\author{
Pedro Payá López \\ Universidad de Alicante
}

\title{
VIOLENCIA, LEGITIMIDAD Y PODER LOCAL. LA CONSTRUCCIÓN SIMBÓLICA \\ DE LA DICTADURA FRANQUISTA EN UNA COMARCA ALICANTINA. EL VINALOPÓ MEDIO, 1939-1948
}


Portada

Créditos

Violencia, legitimidad y poder local. La construcción simbólica de la dictadura franquista en una comarca

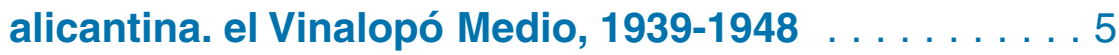

Hacia la integración simbólica. El control de la los medios de comunicación $\ldots \ldots \ldots \ldots \ldots$

El control del territorio. Destrucción y construcción moral . . . . . . . . . . . . . . . . . . . . 12

El paisaje como construcción simbólica . . . . . . 18 Del simbolismo católico al ritual fascista $\ldots \ldots \ldots 22$ La gran protagonista. La Iglesia local . . . . . . . 39

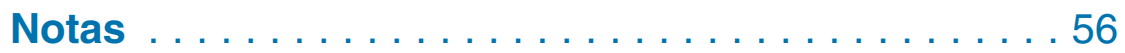


Violencia, legitimidad y poder local. La construcción simbólica de la dictadura franquista en una comarca alicantina. el Vinalopó Medio, 1939-1948

\section{Violencia, legitimidad y poder local. La construcción simbólica de la dictadura franquista en una comarca alicantina. el Vinalopó Medio, 1939-1948*}

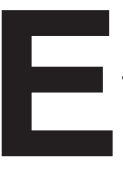

n su aproximación a la naturaleza de la violencia política, el profesor Julio Aróstegui constata dos datos como partida: la existencia de periodos con especial presencia de las relaciones violentas y el cambio observable en las ideologizaciones e instrumentalizaciones de la misma (nota 1). Los años en los que se desarrolló la crisis de los sistemas liberales de la Europa de entreguerras se distinguen como un periodo de extrema utilización de la violencia para solucionar el conflicto social vivido por el avance de la modernidad. En este sentido, la comprensión de la particular experiencia de violencia política vivida en la posguerra espa- 
ñola, pasa por insertarla en este contexto general de crisis de las democracias liberales y auge del fascismo (nota 2).

En el análisis de la consolidación de regímenes políticos dictatoriales como el fascismo italiano se ha puesto de relieve la complementariedad de los conceptos violencia y consenso como instrumentos teóricos para el estudio de la formación social, más allá de una supuesta incompatibilidad entre ambos términos. Por el contrario, se ha constatado que la violencia no sólo actuó para forzar un consenso impuesto, sino como elemento de formación y mantenedor de ese consenso, mediante su ideologización y legitimación, algo que no se puede entender sin la experiencia vivida en la "gran guerra (nota 3)". La guerra no sólo habituó a lo hombres a recurrir a la violencia para solucionar sus problemas, sino que sirvió como factor inspirador del ritual simbólico fascista, con manifestaciones como el culto a los mártires del movimiento (nota 4).

Este tipo de rito es parte de lo que se ha denominado religión política, como máximo esplendor de la sacralización de la política, desarrollada por los regímenes totalitarios. La sacralización de la política, mediante el desarrollo de una serie de mitos, ritos y símbolos perseguirá la legitimación del Estado fascista por la nacionalización de las masas, con la 


\section{Violencia, legitimidad y poder local. La construcción simbólica de la dictadura franquista en una comarca alicantina. el Vinalopó Medio, 1939-1948}

utilización de formas modernas de propaganda y de manipulación, que giran sobre todo en torno a la figura del líder carismático y a la integración en la comunidad nacional para la construcción de un mundo nuevo (nota 5).

Desde este punto de vista, las bases de dominio establecidas por el franquismo tras la guerra civil se basaron en la violencia y en su justificación, mediante una serie de ritos y construcciones simbólicas destinadas a legitimar la implantación del régimen y conseguir un mínimo consenso que permitiera su permanencia. Sin embargo, a diferencia del fascismo, la dictadura franquista no persiguió la nacionalización de las masas, sino, más bien, la integración simbólica de una parte de la sociedad, junto a la exclusión de todo tipo de disidencia. Para ello fue fundamental el papel desarrollado por la Iglesia católica, que acuñó el término de Cruzada, desnaturalizando la guerra civil y permitiendo la división maniquea de la sociedad entre dos grupos antagónicos, representados por la comunidad nacional y un enemigo común: el comunismo (nota 6).

Hay que tener presente, además, la atracción que el fascismo ejerció sobre la derecha conservadora de varios países europeos, entre las que se encuentra la española. Esta atracción explica las concomitancias que existieron entre 
ambos regímenes en algunos aspectos, fruto de la imitación de ciertas características, entre las que destacan las referidas al elemento propagandístico, controlado por el sector falangista del partido único (nota 7). Sin embargo, la nacionalización de las masas que intentó llevar a cabo el grupo falangista, a imitación del fascismo, fracasó ante el mayor peso del componente reaccionario tradicional y católico de los militares y la mayor parte de los grupos que conformaron la coalición reaccionaria, a la vez que chocó con la realidad de una sociedad española desmovilizada por la derrota en la guerra y la represión, que quedó sometida a los medios de control social tradicionales auspiciados por la iglesia católica (nota 8).

La busqueda de legitimidad más allá de la victoria en la guerra civil fue una constante del régimen franquista en su proceso de implantación e institucionalización. No puede existir y perdurar un régimen sin apoyos sociales y entre los que tuvo el franquismo en el ámbito local, hemos estudiado el ejercido por los de la comarca del Vinalopó Medio en la construcción simbólica de la dictadura, a partir de la labor realizada por los poderes locales (nota 9): clero, concejales, militantes del partido y empresarios, que colaboraron en la restauración simbólica que les permitiría sancionar su posición 
Violencia, legitimidad y poder local. La construcción simbólica de la dictadura franquista en una comarca alicantina. el Vinalopó Medio, 1939-1948

de privilegio dentro del sistema social, además de ocupar posiciones en el poder político (nota 10).

\section{Hacia la integración simbólica. El control de la los medios de comunicación}

Tras la ocupación militar de la provincia de Alicante se fueron creando una serie de comisiones de control y de disposiciones que dieron sanción legal a todas las que se habían producido durante la guerra y que supusieron la supresión de todos los referentes republicanos. Amén de la prohibición de todos los partidos políticos y los sindicatos de clase, el control monopolista de la información hizo desaparecer toda una serie de periódicos locales, que habían conocido un gran desarrollo durante las primeras décadas del novecientos (nota 11). De esta forma, fueron suprimidos diversos semanarios locales, quedando las ediciones de prensa reducidas principalmente a las revistas de fiestas y al diario provincial Información, prensa oficial del Movimiento, que en 1941 sustituyó a la Gaceta de Alicante pero que contó unos escasos índices de lectura (nota 12). Aunque teóricamente el control de prensa y propaganda quedó en manos del partido, en su división de competencias con la Iglesia por la política cultural del franquismo, en el ámbito provincial la infor- 
mación fue controlada por el Gobierno Civil, a través del control de los medios de comunicación y la censura previa (nota 13).

Por otra parte, pocos días después del final de la guerra civil, desde la Comandancia Militar de Ocupación se comunicó a los alcaldes de los distintos pueblos la necesidad de controlar los aparatos receptores de radio, reproduciendo en todos sus términos la Orden del Estado Mayor, publicada en la prensa de la provincia el día 25 de abril. En ella se ordenaba a los poseedores de aparatos de radio que no fueran sus propietarios la obligatoriedad de entregarlos en las comandancias militares. Mientras, los que pudieran justificar su propiedad, debían proveerse de las licencias correspondientes en el plazo máximo de 15 días. Las sanciones no eran baladíes, ya que los poseedores ilegítimos de aparatos que no los entregasen en el plazo señalado incurrían en el delito de rebelión militar. Una vez recogidos los receptores en la Comandancia Militar, los que pudieran probar la legítima propiedad del aparato podían recogerlos "siempre y que se trate de personas de reconocida adhesión a nuestro movimiento (nota 14)". La importancia dada a tener controlado el número de aparatos receptores de la provincia hizo que a mediados de septiembre se volviera a insistir en el tema, aun- 


\section{Violencia, legitimidad y poder local. La construcción simbólica de la dictadura franquista en una comarca alicantina. el Vinalopó Medio, 1939-1948}

que por otros medios. Desde la Secretaría del Gobierno Civil se ordenaba al jefe de telégrafos que enviara una relación nominal de los posibles poseedores de aparatos de radio en la provincia (nota 15).

El control de todo tipo de comunicación social llegó incluso al ámbito privado, ordenándose la obligatoriedad de depositar en los buzones de correos toda clase de correspondencia completamente abierta, con el fin de "facilitar la mayor rapidez en la censura", lo que se encargó de ordenar de nuevo la Comandancia Militar a los alcaldes, que debían difundirlo entre el vecindario "por pregón y más medios que tenga a su alcance (nota 16)".

Al mismo tiempo que se coartaba la comunicación libre se producía una propaganda oficial destinada a demonizar todo lo que significara o hiciera, de alguna forma, referencia al periodo republicano (nota 17). Desde las primeras medidas adoptadas por las comisiones gestoras el lenguaje utilizado va en esta dirección, y no dudan en culpar de la situación de escasez en la que se hallaba el ayuntamiento a los representantes de la etapa anterior, como en el caso de Monóvar "como consecuencia de la infame dominación roja, que había dejado al pueblo en casi total situación de ruina." Al mes siguiente, ante la imposibilidad de atender la petición de un 
donativo que el SEU hizo a los municipios de la provincia, de nuevo se recurría a "la penuria económica de este municipio en que le han sumido los rojos. (nota 18)"

\section{El control del territorio. Destrucción y construcción moral}

Desde los centros de poder local se desarrollaron una serie de disposiciones encaminadas a conseguir el control de la población y del territorio, en el que se realizarán una serie de ritos encaminados a la integración simbólica de los vencedores. En este sentido, conviene tener en cuenta la diferenciación que Marcel Mauss hace entre ritos positivos -todos aquellos que hacen referencia a la participación en el ritual de forma activa- y negativos -referidos a toda una serie de tabúes y prohibiciones (nota 19)-. Estas operaciones rituales serán realizadas como mecanismos de socialización, encaminados a la integración simbólica de unos y, paradójicamente, a la exclusión de otros, eliminando una serie de atributos significativos que potenciaban esta integración, a la vez que dejaba sin referentes a los excluídos. En este sentido, hemos de entender la represión más allá de su efectiva aplicación física, como toda una serie de mecanismos encaminados a influir en la voluntad de los reprimidos, desde la 


\section{Violencia, legitimidad y poder local. La construcción simbólica de la dictadura franquista en una comarca alicantina. el Vinalopó Medio, 1939-1948}

amenaza misma que supone la posibilidad del hecho violento, hasta formas de imposición moral y cultural, en cuyo caso el concepto de represión aparece ligado al de control social (nota 20).

Siguiendo esta lógica, el primer paso para la reconstrucción material y simbólica era la ruptura total con todo lo que hiciera referencia al periodo anterior, para lo que se había allanado el terreno por orden de la Comandancia Militar de 16 de mayo, en la que se comunicaba a los alcaldes la necesidad de que, en el plazo máximo de veinticuatro horas y sirviéndose de los medios que creyesen más convenientes "desaparezcan en su totalidad todo letrero, pasquines etc. de propaganda marxista colocados en lugar cualquiera de la población", bajo pena de una severa sanción a sus infractores (nota 21). Antes, el 9 de abril, se había ordenado, desde la Jefatura Provincial de Propaganda que en un plazo de 36 horas fueran borrados de todas la fachadas "los letreros pintados por las hordas del marxismo (nota 22)". Aunque en algunas poblaciones, como la de Elda, las disposiciones generales no se hicieron esperar y, como años después recordaba la prensa local en el aniversario de la "victoria", a la misma entrada de las tropas franquistas "un oficial de alta graduación hizo detener su automóvil en la calle de Queipo 
de Llano, pidió una escalera, y, a martillazos, hizo saltar el mármol que dedicaba hasta entonces aquella calle a Buenaventura Durruti. La columna pasó rápidamente, sin detenerse, en dirección a Alicante. (nota 23)"

A la vez se iban abriendo paso los nuevos símbolos del régimen. La comisión gestora de Elda creaba el 9 de mayo un servicio de inspección de bares y establecimientos públicos, encargado de supervisar "la colocación obligatoria en los mismos de banderas nacionales y retratos del caudillo y José Antonio (nota 24)". Otras decisiones no se hicieron esperar y el cinco de julio se pedía autorización al gobernador civil para proceder al cambio de un gran número de nombre de calles, que se designarían con los nombres propios de la Cruzada. Es común en los trabajos locales sobre el franquismo hacer referencia al cambio en el nombre de las calles, algo que utilizan la mayoría de los regímenes políticos, pero quizá no se haya valorado suficientemente la importancia de la toponimia como medio de construcción simbólica, encaminado a la transmisión de los principales mitos del régimen: El Caudillo, José Antonio, la España Imperial, la Cristiandad y los "Caídos" (nota 25).

Las autoridades municipales también trataron de velar por la catolicidad del Nuevo Estado y crearon comisiones y cam- 


\section{Violencia, legitimidad y poder local. La construcción simbólica de la dictadura franquista en una comarca alicantina. el Vinalopó Medio, 1939-1948}

pañas de supresión de la blasfemia (nota 26), además de controlar todas la actividades publicas de recreo, extendiendo el peso de la moral católica hasta cualquier rincón de la cotidianeidad. La obsesiva vigilancia en el cumplimiento de la moral católica puede verse, sobre todo, en el control sobre bailes, juegos de azar y salas cinematográficas. En febrero de 1940, la alcaldía de Elda tomaba la decisión de no autorizar más bailes públicos que los organizados por sociedades culturales legalmente constituidas (nota 27). Todo ello "por considerar que esta clase de espectáculos contribuían a aumentar la inmoralidad de las costumbres ya de si relajadas por la dominación marxista y que el Estado Nuevo tenia que regenerar (nota 28 )".

Realmente, el control sobre autorización de todo tipo de bailes y fiestas estaba en manos del gobernador civil, al que se habían reservado las competencias de orden público (nota 29). Éste informó a la alcaldía que no se autorizaría la creación de nuevos salones de baile, excepto "aquellos que respondan a una costumbre verdaderamente tradicional...supeditados a cumplir con las oportunas reglas de sanidad... (y a que las autoridades vigilasen) asidua y rigurosamente la fiel observación durante la celebración de los bailes, de los preceptos de la moral cristiana (nota 30)". 
Lo que más preocupaba a las autoridades era la represión sexual. Los bailes eran considerados como caldo de cultivo de pecado con respecto a la moral que, desde el catolicismo integrista, se tenía sobre la sexualidad. Así, desde la Dirección General de Seguridad, Inspección de Investigación y Vigilancia de Elda, se informaba al gobernador civil sobre una denuncia a la empresa de baile "Salón Mundial", en la que "se vienen concertando citas de tipo equívoco con el mayor descaro, lo que hace del mismo un verdadero mercado carnal. Se permite la entrada de menores de uno y otro sexo y se admite también que bailen unidas personas del mismo sexo, lo que da a tal salón un aspecto indecoroso que nada dice a favor de cuantos allí entran". Como consecuencia, el dueño del local fue condenado a pagar una multa de 500 ptas. y el establecimiento fue cerrado por un mes (nota 31).

Otra de las actividades perseguidas fueron los juegos de azar. Absolutamente prohibidos, su persecución llegaba incluso al ámbito privado, como sucedió en la localidad de Monóvar, cuando, por orden del Gobierno Civil, se intervino una Posada en la que se jugaba al "Monte", tal y como había sido denunciado en una carta anónima (nota 32). 


\section{Violencia, legitimidad y poder local. La construcción simbólica de la dictadura franquista en una comarca alicantina. el Vinalopó Medio, 1939-1948}

Más allá de las disposiciones gubernamentales en cuanto a censura de proyecciones cinematográficas y su utilización como medio de propaganda política, lo que nos interesa en la escala local es la vigilancia efectiva que desde las autoridades locales se desarrolló para velar sobre el cumplimiento de la moral católica. En este sentido, el control de las salas de cine también devino obsesivo, dadas las condiciones de nocturnidad en las que necesariamente debían proyectarse las películas. El gestor y delegado de la comisión de espectáculos públicos de la gestora de Monóvar informaba a la alcaldía que "en la sala del teatro dedicada a la proyección de las películas cinematográficas no se guardan el decoro y compostura necesarios que debe presidir y requiere la moral propia del nuevo Estado...haciendo caso omiso de la moral y respeto absoluto que deben guardar públicamente". Quejoso de haber reiterado en varias ocasiones esta situación al empresario del local, pidió al alcalde autorización para "la publicación en la pantalla de una orden gubernativa acerca del comportamiento que había de observarse en la sala de proyecciones". El alcalde le concedió autorización, solicitó la intervención urgente de la policía de espectáculos y mandó citar a comparecencia al empresario de la sala (nota 33). 


\section{El paisaje como construcción simbólica}

En las memorias municipales de 1948, que hacen valoración de las obras realizadas a lo largo de la década, las principales y, a veces, únicas referencias que se hacen es a la construcción de la cruz de los "caídos" y a la reconstrucción de los templos parroquiales, amén de alguna construcción de un gran chalet de un importante industrial de la localidad y alguna pavimentación parcial (nota 34). La construcción del paisaje franquista fue prioritario y abordada desde el principio por los poderes locales (nota 35). Esta trasformación supuso la plasmación de una serie de ritos y símbolos en torno, sobre todo, a dos realizaciones de alto contenido simbólico y en la que, desde una posición u otra, participó la población, sometida o emocionada y no exenta de manifestaciones de júbilo. Me refiero a la construcción de la "Cruz de los Caídos" y al proceso de reconstrucción de las imágenes religiosas y templos parroquiales destruidos durante la guerra civil y que fueron restauradas desde el impulso dado por las autoridades locales (nota 36).

En la serie de ritos que se sucedieron ante estos auténticos símbolos de la "victoria" es donde podemos observar con mayor claridad la confluencia que se dio entre los diversos poderes locales: concejales, empresarios, miembros del par- 


\section{Violencia, legitimidad y poder local. La construcción simbólica de la dictadura franquista en una comarca alicantina. el Vinalopó Medio, 1939-1948}

tido y curas párrocos, sin que se produjera ninguna clase de conflicto entre Iglesia y FET, como pudo ocurrir en las altas esferas del estado (nota 37). Si ambos coincidían ideológicamente en los aspectos básicos referidos a la concepción tradicional de España y el enemigo común del comunismo, las disputas que se sucedieron con respecto al reparto del poder y el control de los medios de socialización no se dieron en estas localidades, en las que éstos fueron compartidos desde la más íntima y fiel colaboración. Las autoridades del partido eran los primeros en acudir a las iglesias, que se engalonaban con las banderas del Movimiento; el Frente de Juventudes contaba con su guía espiritual, los sindicatos también tuvieron su asesor religioso y las escuelas colocaron los principales mitos y símbolos del régimen en sus paredes (nota 38). En el ámbito local el poder era monolítico, ayuntamiento, partido, empresa e Iglesia comulgaron con la restauración ideológica y material con los que a todos premio el nuevo régimen, asegurándose su apoyo, como mecanismo de consenso. En la búsqueda de legitimidad, todos participaron y se beneficiaron de los mitos y símbolos que organizaban el ritual.

Llegados a este punto conviene dejar constancia de la comunión que había entre los intereses de la jerarquía ecle- 
siástica, los del régimen y los intereses económicos y sociales de los principales grupos que lo apoyaron. Jiménez Campo ha explicado cómo las relaciones establecidas en torno a la legitimidad se definen dentro de unas relaciones de intercambio simbólico, que a la vez son condicionadas por otro tipo de relaciones de carácter material, definidas por el conjunto de expectativas experimentadas por la sociedad civil respecto de la acción del poder político (nota 39).

Desde este punto de vista, los apoyos sociales del régimen se vieron beneficiados de una restauración ideológica pero también material. El régimen se encargó de beneficiar a sus principales apoyos sociales, haciéndoles participes de los beneficios de la victoria militar por medio de una serie de premios y privilegios. En primer lugar, devolvió a los empresarios, principales apoyos sociales del régimen en estas localidades, las propiedades que habían sido incautadas y socializadas durante la guerra civil, además de una legislación que permitió la explotación obrera a unos niveles inimaginables (nota 40). Además, en una situación de escasez, que alcanzaba a muchos más de los que podían considerarse como vencidos, premió a una serie de apoyos potenciales, como excautivos, excombatientes, hermanos e hijos de "caídos", permitiéndoles que se beneficiaran de una legislación 


\section{Violencia, legitimidad y poder local. La construcción simbólica de la dictadura franquista en una comarca alicantina. el Vinalopó Medio, 1939-1948}

laboral basada en el privilegio, estableciendo una clara discriminación con respecto al acceso a puestos de trabajo público, que hizo que ayuntamientos y toda clase de organismos públicos se llenasen de personas cuyas cualidades eran los méritos adquiridos en la guerra civil y su fidelidad al régimen. Además, solucionó las posibles dudas que podía despertar entre sus apoyos ante la descompensación que podía haber entre sus mensajes y la realidad inmediata, mediante la demonización del régimen anterior como causa última de las situación de penuria en la que podían vivir.

Los intercambios materiales beneficiaron de una $u$ otra forma a estos grupos, pero no a la gran mayoría. La mayoría de la sociedad civil tuvo que soportar unas condiciones de vida durísimas y fue acallada mediante un sistema de intimidación sostenida, creado por el enorme aparato represivo puesto en funcionamiento por el régimen y que aparece como mecanismo privilegiado de control social (nota 41). En este sentido, si establecemos como principio que un sistema de poder cualquiera se centra para conseguir su legitimidad en medidas que le permitan incorporar más apoyos de los que puede asegurarse por medio de la fuerza "la ruptura de este principio puede estar en el origen de la utilización sistemática de la represión practicada por los regímenes dictato- 
riales (nota 42)". Por ello, la represión aparecerá como el principal mecanismo de implantación utilizado por el franquismo.

\section{Del simbolismo católico al ritual fascista}

El mito de José Antonio constituyó el elemento simbólico más importante entre todas las celebraciones y conmemoraciones efectuadas durante el franquismo. El 20 de noviembre, fecha en que murió José Antonio fusilado en la cárcel de Alicante, fue calificado como día de luto nacional (nota 43). Este fue el día elegido para trasladar sus restos desde Alicante hacia el escorial, tal y como fue decretado por ley de 15 de noviembre de 1939 y, ya en ese momento, adquirió verdaderos tintes de sacralización política (nota 44). Los restos fueron trasladados a pie, pasando por diferentes pueblos que lo recibían en formación. El ayuntamiento de Elda tomó acta del hecho, describiendo el paso de la comitiva por la ciudad, a la que se unieron las autoridades militares y civiles de la localidad. Las calles fueron cubiertas con flores y las Milicias locales escoltaron la expedición en unión de la Sección Femenina y el Frente de Juventudes, presenciando el paso más de 12000 personas. Los restos fueron llevados a hombros por el alcalde y varios camaradas locales hasta la 


\section{Violencia, legitimidad y poder local. La construcción simbólica de la dictadura franquista en una comarca alicantina. el Vinalopó Medio, 1939-1948}

cruz de los "caídos", desde donde, tras rezar un rosario, continuó su andadura (nota 45).

El mito del mártir encarnado por José Antonio se extrapoló a todos los "caídos", en torno a los que se organizó toda una liturgia política, con un sistema propio de símbolos, ritos y mitos de clara inspiración fascista pero de fuerte contenido católico, encaminada a la sacralización del régimen franquista, como mecanismo de legitimación.

El fascismo, ya desde los primeros momentos del escuadrismo o desde el poder, desarrolló una auténtica religión política, construyendo un propio universo de mitos, ritos y símbolos centrados en la sacralización del estado fascista y encaminados a conseguir la nacionalización de las masas, en la que el elemento carismático del "Duce"se convirtió en el principal mito dentro de la liturgia fascista (nota 46). Aunque el mito de los "caídos" tuvo importantes concomitancias con la religión fascista, éstas se redujeron a una mera imitación. Hay que tener en cuanta que, en el caso español, la completa fusión que se había dado entre la Iglesia y el Estado, llegando a conocerse esta etapa incluso como nacional-catolicismo, convirtió este ritual político en ritual católico.

Si en el caso italiano la guerra fue un elemento fundamental en la construcción de la religión fascista, en España la gue- 
rra civil es la que da el sentido a toda la operación simbólica que desarrolló el régimen franquista, a partir del concepto de "Cruzada". En este sentido, si la religión política fascista sacraliza al Estado como manifestación de la comunidad nacional, encaminado a la nacionalización de las masas, en el caso español la falta de un nacionalismo secular llevó a identificar nación con cristiandad, por lo que, en última instancia, los "caídos" lo habían sido por Dios y por la patria, teñida de este sentido de cristiandad (nota 47). Por ello, los mártires y héroes lo fueron en defensa de la religión y de la patria como exponente de la civilización cristiana. Es un claro ejemplo de que un mito político se convierte en religioso, pero dentro del clima creado por la España franquista, en el que lo difícil era diferenciar entre religión y política.

El sentimiento de causa común y pertenencia a la comunidad nacional que representaba el mito de los "caídos" se contempla en disposiciones que se trataron de llevar a cabo en los primeros años. Desde el ayuntamiento de Alicante se exhortó a todos los municipios de la provincia para que trasladasen los restos de "sus caídos" a una Capilla que se mandó construir en el cementerio municipal de la capital, con un "departamento especial dentro de aquella, pero independizado, donde deben ser reinhumados los restos de la Caídos 


\section{Violencia, legitimidad y poder local. La construcción simbólica de la dictadura franquista en una comarca alicantina. el Vinalopó Medio, 1939-1948}

por Dios y por la Patria en Alicante, durante la guerra de liberación de España (nota 48)".

Sin embargo, la oferta no fue aceptada. Los vínculos con los mitos de la nueva religión política -vínculos sobre todo nacionales- no eran tan fuertes como para separar a los restos de la inmediatez del catolicismo familiar, los lazos de la comunidad con el fenómeno religioso seguían siendo profundamente locales (nota 49).

El culto a los "caídos" se convirtió en el referente falangista más importante de cara a la propaganda política del régimen. En las iglesias de todas las localidades de la provincia se gravaron los nombres de los "caídos" pertenecientes a cada parroquia, encabezados por el de José Antonio. Destaca el hecho de que en Elda, donde no había iglesia porque había sido totalmente destruida, la comisión gestora aprobase "la adquisición de una lápida con una cruz de mármol en la que figuren el nombre de los caídos por dios y por España, encabezados con el de José Antonio y que será colocada en la fachada del ayuntamiento hasta que haya iglesia (nota 50)".

El día 30 de junio los restos de los "caídos" de distintas localidades, que habían sido fusilados por sentencia del tribunal popular de Alicante, eran trasladados a sus lugares de 
origen en la provincia. Se les recibía como auténticos mártires y se celebraban actos recubiertos de gran solemnidad. En el pueblo de Petrer fueron enterrados en el suelo de la Iglesia parroquial.

Desde la Jefatura Local de FET-JONS se publicaron numerosas esquelas que aludían a su calificación como mártires del marxismo, "caídos por Dios y por España": "cayeron nuestros Mártires por la redención de España. El marxismo destructor de toda idea de grandeza, Dios, Patria, Religión, Familia y Justicia, supo elegir sus víctimas: Por eso cayeron ellos, los mejores, los más justos, los que podían con su esfuerzo elevar la patria y salvar la civilización." Implícitamente se justificaba la acción violenta contra el "enemigo" encarnado en "el marxismo demoledor, del que no debe quedar raíz que haga posible el retoñar de su barbarie."

El sentido totalizador en el que se desarrollaba la propaganda de FET desde la Jefatura Local advertía sobre la conveniencia de que el acto de los "caídos" debía ser ejemplo para todos, por lo que: "La escuela, forja de hombres del mañana debe colocar sus retratos en las aulas y con una oración diaria deben explicar los maestros la virtud de su sacrificio. En cada hogar, junto a los viejos retratos familiares, debe existir también el de estos hermanos que con su vida nos 


\section{Violencia, legitimidad y poder local. La construcción simbólica de la dictadura franquista en una comarca alicantina. el Vinalopó Medio, 1939-1948}

han legado el disfrute de un mundo mejor. $Y$ en las oficinas, en los comercios, en las fábricas y en cuantos sitios, en fin, sean punto de convergencia para los hijos de Petrel, la efigie de nuestros mártires debe servir de escolta a la del caudillo Franco y a la del embajador de España en el Cielo, José Antonio. (nota 51)"

De especial significación fue el traslado de los restos de Luis Batllés, consejero nacional de la Falange y hermano de un alcalde significativo en estos años, José María Batllés, quien, como alcalde de Elda, intentó dar un verdadero aire falangista a la política local, lo que le causó fuertes enfrentamientos con la derecha tradicional y su sustitución desde el Gobierno Civil (nota 52). La llegada de los restos se rodeó de una pomposidad extraordinaria. Fueron trasladados en la noche del 28 de octubre de 1942, víspera de la inauguración del monumento a los "caídos" de Elda. El féretro fue colocado en la capilla ardiente instalada en la Jefatura Local de FET, donde miembros de las Milicias de Falange le dieron guardia hasta la mañana siguiente, en la que el gobernador civil, junto al alcalde y jefe local José María Batllés, acompañados por las Milicias, Sección Femenina, Frente de Juventudes y representantes de las diferentes delegaciones sindicales de la provincia, visitaron la capilla para orar ante 
los restos del "caído" como primer acto antes de pasar a inaugurar el monumento (nota 53).

La cruz de los "caídos" fue sin duda la primera obra en la que se centraron las nuevas corporaciones. Disponemos de una memoria de la comisión pro-construcción del monumento a los "caídos", realizada por las autoridades de Petrer. Nos interesa en tanto aparecen las distintas fuentes de financiación que colaboraron en la construcción, en las que se refleja claramente la comunión de intereses entre autoridades civiles y religiosas, junto a los principales empresarios de la localidad. Las relaciones entre la construcción simbólica y los intereses meramente materiales quedan de manifiesto en el impulso que los industriales de la localidad dieron a la construcción de la cruz. Antes habían recuperado las empresas socializadas durante la guerra civil y veían en la permanencia del nuevo estado una garantía de seguridad, además de comulgar con su ideología tradicional y católica.

En sesión celebrada el 16 de abril de 1939, cuando no llevaba siquiera dos semanas funcionando la comisión gestora, la corporación muestra su deseo de levantar un mausoleo que perpetúe la memoria de los "caídos", "mártires de la causa nacionalista, fusilados en Alicante por el gobierno rojo, así como de otros buenos patriotas de la localidad, per- 


\section{Violencia, legitimidad y poder local. La construcción simbólica de la dictadura franquista en una comarca alicantina. el Vinalopó Medio, 1939-1948}

seguidos encarnizadamente por sus ideas religiosas y derechistas, que fueron asesinados de manera alevosa y criminal en vías públicas por las hordas marxista (nota 54)."

Para llevar a cabo la construcción del monumento se nombró una primera comisión formada por Nicolás Andreu Maestre, que un mes depués fue nombrado alcalde, cargo que desempeñará, junto al de jefe local, hasta 1968. Junto a él, Hipólito Navarro Villaplana, excautivo, y Santiago García Bernabeu, socio de una de las principales industrias de calzado de la comarca, alcalde entre 1934-36 y futuro gestor. Para llevar a cabo el proyecto se formalizó una subscripción popular encabezada por el ayuntamiento y se decidió que el monumento debía quedar emplazado enfrente de las escuelas nacionales, lugar significativo que muestra la importancia dada por el régimen a la escuela como elemento adoctrinador, más que educador. El adoctrinamiento ideológico comenzaba en la más temprana edad.

Un año después, en agosto de 1940, el alcalde convoca a 34 personas, en su mayor parte industriales del calzado, aunque también había propietarios de canteras y otras industrias como la cerámica, junto a otros con peso específico en la localidad, para tratar de asuntos relacionados con la construcción del monumento (nota 55). El motivo de la convoca- 
toria fue formar una comisión encargada de recaudar fondos para la construcción del monumento, integrada por José María Poveda, delegado local de sindicatos, Alfonso Chico de Guzmán, representante de la patronal, y Juan Bautista Navarro, representante de los obreros y militante en FE con anterioridad a 1936. Lo que realmente se decidió fue recaudar el sueldo de un día de trabajo, que donarían "voluntariamente" los trabajadores para la construcción del monumento. El dinero se encargó de recaudarlo la Delegación Local de Sindicatos, pero eran los empresarios personalmente los que entregaban la parte correspondiente de los sueldos de los obreros (nota 56). El día elegido para la donación del sueldo contaba con gran carga simbólica ya que se trataba del 17 de octubre, aniversario de los "caídos" de Petrer (nota 57).

En la memoria se enumeran las diferentes fuentes de ingreso. De los sueldos de los obreros, la Delegación Local de Sindicatos recaudó 7.861ptas., mientras los empresarios, por su parte, contribuyeron, mediante donativos, con un total de 12.880 ptas., entre los que destacan los realizados por las principales industrias del calzado de la localidad: Calzados Luvi, con 5.000; García y Navarro, 2.000 y Chico de Guzmán, 2.000. Es significativa, en unos años de esca- 


\section{Violencia, legitimidad y poder local. La construcción simbólica de la dictadura franquista en una comarca alicantina. el Vinalopó Medio, 1939-1948}

sez, de "Juntas del plato único" y de "días sin postre", la recaudación que se hizo desde la Delegación de Abastecimientos, por la renovación de Tarjetas de tabaco, 5.700 ptas y de tarjetas de abastecimiento, 5.300 ptas. El total de las 62.886 ptas. que se destinaron a la construcción se completa con 20.000 ptas. recaudadas por la rifa de una casa y con 8.670, como suma de donativos particulares (nota 58).

Las fechas clave se convertirán en punto de encuentro de autoridades y población ante el monumento. El ritual que se producía recuerda mucho al realizado por los fascistas en Italia, en el que tiene gran importancia la simbología de la muerte y la resurrección ante la comunidad, junto a la mística de la sangre, el sacrificio por la nación y el culto a los mártires y a los héroes. Todos estos elementos del ritual derivaron de la experiencia en la "gran guerra" y estuvieron ligados a la mitificación de ésta como "gran evento regenerador" (nota 59). Sin embargo, en el caso español, la influencia mayor deriva de la tradición católica, los ritos son, sobre todo, de carácter eclesiástico, buscando la confluencia de religión y modelo fascista.

El ritual de los "caídos" representa la manifestación más solemne de la liturgia franquista y en ella se plasmaba la justi- 
ficación de la violencia política, como mecanismo de implantación y dominio político, dentro del sistema de mitos y símbolos que lo componían. Sin duda, el rito servía para representar la integración de todos los apoyos del régimen en una comunidad definida por unos mismos intereses y valores, que correspondían a una misma visión de su universo simbólico. En este sentido, es clarividente la definición que hace Durkheim de los ritos, para el que son, ante todo, "los medios por los que el grupo social se reafirma periódicamente...hombres que se sienten unidos, en parte por lazos de sangre, pero aún más por una comunidad de intereses y de tradiciones, se reúnen y adquieren conciencia de su unidad moral (nota 60)".

Podemos analizar el ritual, teniendo en cuenta los distintos factores que intervienen en él, desde distintos puntos de vista (nota 61). Entendido como un conjunto de medios simbólicos ordenados para alcanzar los fines propuestos, el lugar aparecía como un santuario, en el que tanto los objetos significativos -como las fotos de los "caídos", banderas o signos del partido- junto a las actitudes -como el brazo en alto a "la romana", la posición de firmes, el canto del "Cara al sol" o la Oración Sagrada- hay que considerarlos en su función integradora. Como estructura teleológica de los valores, las op- 


\section{Violencia, legitimidad y poder local. La construcción simbólica de la dictadura franquista en una comarca alicantina. el Vinalopó Medio, 1939-1948}

ciones primordiales se expresan con un lenguaje alusivo, en el que el grito a los "caídos", que venía respondido de "presente" tiene una clara derivación del "rito dell'appello" fascista (nota 62). Al contenido cognoscitivo se añade una resonancia afectiva relacionada con la participación, la emoción y la memoria de los "actores" y espectadores.

Las manifestaciones ante la cruz no sólo sirvieron como lugar sagrado en el que desarrollar la liturgia política sino que, además, aparece como espacio privilegiado de sometimiento, si bien una y otras cosa eran parte de un ritual basado en la distinción entre vencedores y vencidos. Desde este punto de vista, hemos de contemplar el ritual como un conjunto de papeles, en el que la situación de los presentes y su posición en la liturgia funciona según un eje control-dependencia, que destaca las relaciones asimétricas interindividuales, la reciprocidad de los papeles y la existencia de ideales comunes (nota 63). En este sentido, es significativa la posición en que se vivía el ritual y el carácter de sometimiento que en los primeros años tuvo hacia una parte de la sociedad: los obreros, considerados sospechosos por su proximidad al marxismo, eran obligados a asistir a la cruz de los "caídos" en fechas clave como el 18 de Julio, calificado por el régimen como "día de exaltación del trabajo". 


\section{Pedro Payá López}

Desde la Jefatura Comarcal de Sindicatos de Elda se enviaron circulares a todos los empresarios en las que se daba instrucciones de cómo debían participar en el ritual tanto empresarios como obreros "con el fin de conseguir una perfecta organización en los actos a celebrar". Cada empresa debía reunir en su local a todos sus obreros a las ocho de la mañana, "Acto seguido y con su Empresario al frente se marchará en formación a la Cruz de los Caídos, donde se celebrará la Misa de Campaña, debiendo estar sin excusa ni pretesto en el lugar que se señalará a cada Empresa a las ocho y media en punto de la mañana."

Las empresas debían formar dentro de sus sindicatos correspondientes, llevando cada una al frente una pancarta con su nombre. Al frente de cada sindicato también debía ir su jefe local. La asistencia a los actos era de inexcusable obligatoriedad para todos, y debían ir "por decoro y dignidad vestidos correctamente." Finalmente, como cierre de los actos "se procederá a desfilar, como en años anteriores, ante las Autoridades locales, esperando de todos que el comportamiento de cada uno en el desfile sea una prueba más de adhesión a nuestro Caudillo, salvador de España en fecha tan memorable (nota 64)". 


\section{Violencia, legitimidad y poder local. La construcción simbólica de la dictadura franquista en una comarca alicantina. el Vinalopó Medio, 1939-1948}

No eran éstas la únicas ocasiones en que los trabajadores eran reunidos en sus fabricas para participar en los actos del régimen, durante un tiempo en Petrer "a los trabajadores se les obligaba a acudir los domingos a sus fábricas para ser llevados en columna de a dos a oír la Santa Misa (nota 65)".

Aún así, no debemos establecer una rígida división de clase, pues había trabajadores que comulgaban con los ideales del régimen, aunque normalmente formaban con los miembros de FET, escoltando a la gran mayoría. Sin embargo, hemos de tener en cuenta que desde el régimen sí se dio a la victoria un componente de clase, desde el momento en que los empresarios fueron desde el principio beneficiados, ocupando posiciones de poder y beneficiándose de una legislación laboral que los convirtió en auténticos jefes de empresa (nota 66).

Hemos comentado el referente a la guerra como explicación del contexto en el que se desarrolla la violencia. Hemos de tener en cuenta, en este sentido, la inmediatez de la violencia en el conflicto desarrollado en el ámbito local, y de especial repercusión- por la zona de la que se trata- de la represión que tuvo lugar en el bando republicano y en la que tuvo especial trascendencia, para una gran parte de la población, la represión por las actitudes religiosas. Esta, creo, es una de 
la claves que da respuesta a lo que en definitiva se pregunta este trabajo: ¿qué cambios pudieron darse en la formación social española para que los ciudadanos aceptaran la violencia como un medio, no ya para llegar al poder, sino para mantenerlo, apoyando la implantación y consolidación de un régimen que, sobre todo, se mantuvo por la institucionalización de la violencia y la exclusión de una gran parte de la sociedad?

Para dar respuesta hemos de partir de una premisa. Hemos de tener en cuenta que el concepto de poder político tiene que ver con el monopolio de la fuerza por parte del Estado, por lo que deviene en fuerza legal, trasladando a la ilegalidad cualquier otra manifestación de fuerza que no venga de la ejercida por el monopolio que de ella tiene el Estado (nota 67). Por ello -y partiendo de la premisa que todo poder político busca la legitimación más allá de la legalidad que le proporciona su sanción institucional- lo que trata de conseguir la legitimación es la aceptación de ese monopolio de la fuerza por parte de los gobernados. Lo que se trata de justificar es la utilización de la violencia por el Estado para conseguir sus objetivos. En última instancia, la búsqueda de legitimidad del franquismo pasó por justificar la utilización de la violencia, para lo que se recurrió a la ideologización de la 


\section{Violencia, legitimidad y poder local. La construcción simbólica de la dictadura franquista en una comarca alicantina. el Vinalopó Medio, 1939-1948}

patria, en el sentido más arriba mencionado y a la moral católica.

Por ello, la respuesta está en los mecanismos de socialización que desarrolló el régimen, basados en las formas de control social tradicionales en los que la voz principal vino dada por la Iglesia católica. En este sentido, aunque el rito de la cruz de los "caídos" fue de inspiración fascista, el principal componente ideológico del universo simbólico de este ritual vino de la religión católica, desde el momento en que la jerarquía calificó la guerra civil, y con ello el conflicto social que se había producido en España, como Cruzada. En este sentido, la Cruzada adquiere pleno significado cuando se especifica el enemigo, que no era otro que el comunismo internacional, con lo que no sólo se evitaba hablar de guerra civil (nota 68), también se excluía a una parte de la sociedad española de los valores patrios, monopolizados por los vencedores. Las connotaciones de esta distinción abrían la puerta a la legitimación de la violencia, si tenemos en cuenta las palabras de Zenon Davids "La violencia es intensa cuando se liga íntimamente con los papeles fundamentales y la autodefinición de una comunidad (nota 69)". La sacralización de la cruz de los caídos era importantísima, porque ante ella se explicitaba esta distinción de forma solemne. 
Además, desde el punto de vista moral, lo que, en definitiva, encarnaban las dos fuerzas enfrentadas, era el bien y el mal, lo cual contenía implicaciones políticas y sociales de gran trascendencia, ya que los grupos sociales y partidos políticos que estuvieran detrás de uno u otro principio eran intrínsecamente malos o buenos (nota 70). Esta visión siempre estuvo presente en el ritual de los "caídos": el mal, entendido desde la doble concepción en la que se expresa la cosmovisión católica y que muy bien ha descrito Norberto Bobbio, distinguiendo entre mal infringido y mal sufrido (nota 71). Para Bobbio, de la derivación de esta doble concepción del mal se entiende la existencia de un daño infringido y un daño sufrido, lo que constituye también una doble visión del concepto de pena, como pena sufrida y pena como concepto jurídico de castigo. Teniendo en cuenta que la pena sufrida es anterior al castigo, éste aparece así como algo ejemplarizante, cuestión fundamental para entender la violencia política ejercida desde el poder en las dictaduras, que buscan su exhibición pública como ejemplo aleccionador del que se deriven actitudes, no sólo de sumisión y desmovilización (nota 72), también de aceptación por parte de los que colaboran en el hecho violento. Para ello, la instrumentalización de la moral católica devino en mecanismo idóneo para aplacar la voz de la conciencia. 


\section{Violencia, legitimidad y poder local. La construcción simbólica de la dictadura franquista en una comarca alicantina. el Vinalopó Medio, 1939-1948}

\section{La gran protagonista. La Iglesia local}

La Iglesia se va a erigir, pues, en la institución principal cara a la legitimación del franquismo, brindando su apoyo doctrinal y participando en el entramado político del régimen (nota 73). Volvió a ocupar el espacio público del que había sido apartada durante el periodo republicano, multiplicándose las manifestaciones litúrgicas durante estos años. Por medio de todo tipo de fiestas religiosas, romerías, vía crucis, procesiones, santas misiones, la Iglesia se desplegó como una realidad por todo el territorio, proyectándose más allá de lo que Durkheim calificó como lugares sagrados propios de la sociedad religiosa: los templos (nota 74 ).

Ahora bien, hemos de tener en cuenta que estas manifestaciones religiosas se van a revestir de un claro contenido político, porque en ellas adquieren gran protagonismo las autoridades locales, por lo que se convierten en lugares privilegiados para plasmar la unidad entre poder político, económico y religioso (nota 75 ).

Las misiones se desarrollaron, sobre todo, entre los siglos XVI-XVIII y se diseñaban para cristianizar a las poblaciones de las colonias, así como las de Europa que desconocían los rudimentos de la fe. En el mundo moderno se asientan sobre una visión muy concreta, cuyos elementos definitorios son: 
el ideal de sacrificio personal como vía de santificación personal, pero también, el servicio al prójimo (caridad), entendido dentro de unos límites muy determinados: la conversión. Se distinguen, sin embargo, dos tipos esenciales de misión según el acento que se pone en la enseñanza de la doctrina o en la afectividad. Así, la penitencial (jesuitas, capuchinos) busca conmover a las audiencias con múltiples recursos sonoros, visuales, que abundan en la emoción como eje de la conversión. La misión se concibe así como un "choque" que pretende introducir a los fieles en las devociones, la oración y la confesión como elementos de consolidación del camino emprendido. Por otro, está la catequética que no utiliza recursos espectaculares o teatrales, sino que pretende adoctrinar y enseñar el catecismo a los fieles, lo que supone una mayor duración (nota 76).

El deseo recristianizador de la Iglesia, respaldado y potenciado por las autoridades locales, hizo que también durante el franquismo fueran organizadas una serie de "Santas Misiones" -siempre con carácter penitencial- encaminadas a recristianizar a la población, y en las que tuvo gran importancia la consideración de la provincia de Alicante -última zona republicana de la guerra civil- como un territorio especial a reconquistar y al que se le dio gran significado simbólico. 


\section{Violencia, legitimidad y poder local. La construcción simbólica de la dictadura franquista en una comarca alicantina. el Vinalopó Medio, 1939-1948}

Además, cuando el elemento a cristianizar era el obrero, en una zona de gran tradición socialista y anarquista, las "conquistas" se celebraron con júbilo y aires triunfales (nota 77).

En la comarca se realizaron varias "Santas Misiones". La primera se llevó a cabo en abril de 1940 en Monóvar. Los Padres Misioneros fueron recibidos a la entrada del pueblo por las autoridades civiles y militares y conducidos al templo donde se oficiaba una misa que daba comienzo a la misión. Ésta duraba varias semanas, durante las que se realizaban una serie de ceremonias encaminadas a reavivar los sentimientos religiosos del lugar. De esta forma, todos los días a las seis de la mañana tocaba "Misa dialogada"; los martes, miércoles y sábados, "Rosarios de la Aurora", que presidía el alcalde y jefe local de FET, y por la noche, "todos los días de siete a nueve los principales actos de la Misión; Santo Rosario, Letrillas cantadas, Exposición Apologética en forma dialogada y sermón moral (nota 78)". Destaca la visita de los Padres Misioneros a las cárceles del partido judicial en las que "dieron conferencias Apologéticas y Morales a los reclusos, terminando tan provechosa labor con una Misa y comunión general para toda la población penal, con Asistencia de las Autoridades, Jerarquías e invitados (nota 79)". Se consi- 
deró un enorme éxito el hecho de que se acercaran a comulgar más de setecientos reclusos.

Desde la etnología y la antropología cultural se ha estudiado la importancia de las fiestas para la población y su participación como elemento a la vez de integración y singularidad, en la que el hombre común adquiere significativa importancia al ocupar un papel principal dentro de la celebración (nota 80). Sin embargo, en las fiestas locales celebradas durante estos años, fiestas de carácter religioso pero con gran contenido político, esa posibilidad suponía una dignidad reservada a unas pocas autoridades, identificadas con el poder local. De tal forma, las autoridades ocuparían las principales posiciones y protagonismos en las fiestas, destacando sobre todos los demás, ya que servían para guardar celosamente el principio de jerarquía, tanto en las relaciones de dominación política como en las sociales (nota 81).

Son válidas, en este sentido, las memorias de algunos monaguillos de la época: "Las autoridades que acudían a la procesión tenían santo y seña, hacían arrodillarse a la gente a golpes y por llevar la boina mal puesta cuando pasaba el palio te daban un cachotazo. Antes de comenzar las procesiones el alguacil llevaba un capazo de velas nuevas y usadas. 


\section{Violencia, legitimidad y poder local. La construcción simbólica de la dictadura franquista en una comarca alicantina. el Vinalopó Medio, 1939-1948}

Al alcalde y concejales se las daba para estrenar y a los allegados las otras (nota 82)".

Dentro del templo también se reproducía la jerarquía social: "Muchas mujeres pudientes tenían sus reclinatorios personales, de su propiedad, y claro, al faltar sillas se cogían los reclinatorios vacíos para sentarse o arrodillarse. El lío se producía cuando llegaba alguna dueña y su reclinatorio estaba ocupado (nota 83)."

Las fiestas patronales, que fueron prohibidas en 1935, volvían a organizarse, esta vez con una especial significación de reconquista del espacio y revancha. Las fiestas típicas de la comarca eran las de Moros y Cristianos y sirvieron para instrumentalizar una nueva visión de la "Reconquista", haciendo un claro paralelismo con el concepto de Cruzada. La presentación de las fiestas, en las que no hay que despreciar la importancia del lenguaje, utilizado como elemento de construcción simbólica, dejaba claro el nuevo sentido que se les daba, y el mero hecho de volver a celebrarse se interpretaba como un triunfo ante el enemigo. En mayo de 1940 las autoridades de Petrer presentaban así la vuelta de sus fiestas patronales:

"iMoros y Cristianos! Fiestas de Reconquista, Fiestas de Independencia y de Liberación en los albores del 
Imperio hispánico...Fiestas de un simbolismo bien perfilado: Reconquista, valor indómito, patriotismo de un pueblo y tenacidad de una raza que lleva la Cruz en sus estandartes y en su corazón la fe de Cristo...Recuerdo de glorias nuestras...Reyes gloriosos que, hermanando la espada con la Cruz, libertaron a la Patria de fueros extraños, forjando a la vez, la unidad de nuestra raza en haz de la hermandad".

Pronto, lo que quedaba implícito en este alegato se explicitará claramente:

" España! Ahora y siempre en la vanguardia defensiva de la civilización cristiana. Antaño contra la invasión árabe que amenazaba anegar Europa. Ahora, contra el bolchevismo asiático que pretendía asfixiar -para siempre- los limpios valores espirituales de esa misma civilización cristiana."

El discurso no dejaba pasar por alto todo un "acontecimiento histórico", producto de la modernidad, en clara alusión a la retórica franquista de construcción de algo nuevo y que tan solemnemente se plasmaba en los documentos oficiales con la referencia al Año I de la Victoria: 


\section{Violencia, legitimidad y poder local. La construcción simbólica de la dictadura franquista en una comarca alicantina. el Vinalopó Medio, 1939-1948}

"Y la Historia, en uno de sus cambios admirables, nos ofreció el magnifico ejemplo del pueblo marroquí, que veló a nuestro lado y derramó su sangre junto a la nuestra, en esta moderna y doble Cruzada de patriotismo y de fe... Y todo, bajo el cielo azul de Mayo, claro y riente como el amanecer de España (nota 84)."

El poder político local se encargó de satisfacer las demandas de la Iglesia. Tras la política de destrucción y demonización de los referentes anteriores vino la reconstrucción, mediante la restauración ideológica -con toda la serie de medidas encaminadas a velar por el cumplimiento de la moral católica- y la material -mediante una serie de subvenciones y donaciones- destinadas a la reconstrucción de los Templos e imágenes profanadas durante la guerra civil.

Para llevar a cabo la labor de recristianización era urgente rehabilitar los templos que habían sido destruidos o incendiados durante la guerra civil. Para ello, en junio de 1941 se creo una Junta Nacional para la Reconstrucción de Templos Parroquiales, y tres meses después una diocesana (nota 85). Anteriormente, desde los primeros meses, los nuevos ayuntamientos plantearon la reconstrucción o restauración de los templos y ermitas. Para ello se constituyeron en cada localidad diferentes comisiones pro-reconstruc- 
ción de los templos parroquiales, en cuya composición podemos observar las relaciones entre los diversos poderes locales, ya que estaban integradas, en la mayoría de los casos por el cura párroco, el alcalde, el presidente de Acción Católica, concejales y un nutrido grupo de empresarios.

En Elda, la iglesia había sido totalmente destruida, quedando únicamente la planta donde había estado emplazada. Por esta razón, hasta la construcción del nuevo templo se improvisó uno en un antiguo salón de baile, que fue bendecido a tal efecto. Ya en estos primeros años, la plena comunión entre la Falange local y la Iglesia quedaba de manifiesto en la celebración de las Misas Mayores, en las que el templo habilitado era decorado con las banderas Nacional, de Falange y Tradicionalista, en presencia de las Milicias de Falange presentando armas, los cuadros de las tropas de ocupación formados, la Sección Femenina y las Organizaciones Juveniles (nota 86).

En los primeros meses, el nuevo ayuntamiento comenzó a plantear la reconstrucción del templo parroquial de Santa Ana, proyectando la "urbanización de la zona urbana lindante con la plaza donde a de ser reconstruida la Iglesia Parroquial, al objeto de que ésta tenga en su día un emplazamiento digno de la misión divina" (nota 87), y cediendo 


\section{Violencia, legitimidad y poder local. La construcción simbólica de la dictadura franquista en una comarca alicantina. el Vinalopó Medio, 1939-1948}

gratuitamente el valor de la enajenación de "cinco solares edificados con una sola planta ...cuyas edificaciones se realizaron con fondos municipales en época roja." (nota 88) Con ello el ayuntamiento promovía una suscripción para la reconstrucción del templo, que encabezaron los principales industriales de la ciudad, a lo que se añadía la donación por el Estado de 500.000 pesetas (nota 89). En sesión del 15 de febrero de 1940, también se decidía la reconstrucción de la ermita "en contraposición y para reparar la ofensa cometida por el primer ayuntamiento republicano a los sentimientos católicos de la ciudad al acordar demoler por supuesta ruina la Ermita de San Antón". Y más adelante se destinaban 20.000 pesetas para subvencionar la ornamentación del altar mayor de la iglesia Santa Ana. (nota 90)

En Petrer no se contó con ninguna ayuda estatal ni diocesana, la obra de reconstrucción se hizo por el impulso fundamental del párroco, junto a las autoridades municipales, que contaron con la aportación de los empresarios de la localidad. En diciembre de 1940 el alcalde y jefe local reunió en su despacho a los principales industriales de la localidad con el fin de "tratar asuntos de carácter extraordinario y de sumo interés local, especialmente de los trabajos de construcción de aguas potables de esta villa, otros de necesidad y reco- 
nocida urgencia como es la construcción y reparación de desperfectos de la Iglesia parroquial, devastada durante la dominación marxista y atenciones indispensables de las Organizaciones de Falange de la localidad." Ante el Ilamamiento del alcalde a que demostrasen su "catolicismo y adhesión al régimen" los empresarios acordaron donar el 0'40\% del importe de los productos fabricados en el término, destinando el $50 \%$ del mismo para la distribución de aguas potables y el otro $50 \%$ para la reconstrucción y reparación del templo parroquial (nota 91).

La comisión Pro-Reconstrucción Iglesia Parroquial y Casa Abadía de Petrer, realizó una memoria en la que se detallan las diferentes aportaciones que sufragaron la reconstrucción del templo, entre 1940-1946 (nota 92). Su presidente es el alcalde y jefe local Nicolás Andreu Maestre y como vocales, además de los curas párrocos que se sucedieron durante estos años, aparecen los gestores Enrique Amat Payá, Santiago García Bernadeu, importante industrial del calzado y alcalde entre 1934-36, Ricardo Villaplana Reig, presidente del Sindicato Local de la Piel y socio de Calzados Luvi, empresa con más de 350 trabajadores, de las más importantes del sector, además de José Tortosa Poveda, delegado local del Frente de Juventudes. 


\section{Violencia, legitimidad y poder local. La construcción simbólica de la dictadura franquista en una comarca alicantina. el Vinalopó Medio, 1939-1948}

Para la reconstrucción del templo se consiguieron recaudar un total de 277.057 ptas. La Delegación Local de Abastecimientos aportó 8.400 ptas. de la renovación de cartillas de tabaco, que se sumaban a las 48.520 ptas obtenidas de donativos particulares. Pero fueron de nuevo los industriales quienes más aportaron para la reconstrucción del templo, con 202.863 , casi un $75 \%$ de la suma total, 41.400 procedentes del canon industrial acordado y el resto de donativos particulares de los empresarios. De nuevo encontramos entre los principales, a los que ya habían colaborado en la construcción del monumento a los "caídos", con las 42.624 ptas. entregadas por Calzados Luvi, y las 17.187 de García y Navarro, misma cantidad que entregó la empresa A. y F. Chico de Guzmán.

No fue en vano el esfuerzo industrial, la Iglesia respondió como correspondía y colocó una placa conmemorativa en el interior del templo que todavía hoy podemos contemplar, en la que se dice: "Este templo, profanado e incendiado durante la revolución de 1936 fue reconstruido por iniciativa del cura párroco don Vicente Marhuenda Gran con el esfuerzo y aportación de los industriales y propietarios de esta villa." La Iglesia, una vez más, se encargaba de distinguir a quienes más habían colaborado para su engrandecimiento. Eran los 
mismos que colaboraban con el régimen y que volvían a tener los medios de producción en sus manos. Pero olvidaba los donativos del otro $25 \%$ que también había contribuido a la reconstrucción del templo.

Los espacios públicos se van diseñando no solo para los vivos, también para los muertos, estableciendo distinciones que no podía pasar por alto el nacional-catolicismo. La comisión gestora del ayuntamiento de Elda aprobó que el nuevo cementerio "conste de un recinto principal destinado al enterramiento de los católicos y otro de menos extensión destinado a la sepultura de los restos de las personas que no tuvieran aquella condición...Ambos recintos permanecerán debidamente separados con pared que los independice y con puertas de entrada distintas (nota 93)".

El tipo de religiosidad que se implantó se caracterizó por el predominio de las manifestaciones externas y la invasión de todo el territorio municipal, convertido en espacio público de socialización, de integración simbólica y de sometimiento (nota 94). Por ello, una de las más importantes demandas de la Iglesia local a las autoridades fue la reconstrucción de las imágenes que habían sido profanadas y quemadas durante el brote anticlerical. Las imágenes se convertían en punto fundamental para llevar a cabo la deseada recristianización 


\section{Violencia, legitimidad y poder local. La construcción simbólica de la dictadura franquista en una comarca alicantina. el Vinalopó Medio, 1939-1948}

y adquirieron enorme carga simbólica mediante su traslado en las procesiones, sobre todo en las de reposición ya que, en cierta medida, para el imaginario colectivo eran representadas como víctimas de la "barbarie roja", con lo que encontraban cierto paralelismo con el mito de los "caídos".

De nuevo las fronteras entre política y religión estaban poco claras dentro del nacional-catolicismo, y ello porque, desde un principio, el régimen y la jerarquía eclesiástica estuvieron dispuestos a instrumentalizar las creencias religiosas de una buena parte de la sociedad española, especialmente aquella identificada con el bando vencedor (nota 95).

Fueron de nuevo los principales empresarios, junto a las autoridades civiles, los que donaron las imágenes. Las relaciones entre el poder político, económico y la Iglesia se plasman en el ritual que conllevaba la reposición de estas imágenes, en los que la solemnidad con que se producían alcanzaba de lleno a los donantes. La bendición se hacía en el propio domicilio de éstos o en los mimos locales de sus industrias, desde donde se llevaban en procesión a la parroquia. Era el inicio del ritual, en el que los donantes tenían principal protagonismo, con lo que crecía la credibilidad de su papel en la vida pública. De esta forma sacralizaban su 
posición de poder y legitimaban su estatus dentro de la estructura social tradicional, defendida por la Iglesia católica.

De nuevo aparecen los nombres de los principales industriales que habían colaborado en las reconstrucciones de los templos o en las construcciones de los monumentos a los "caídos". En Monóvar fue bendecida una imagen en los locales de Carlos Tortosa, alcalde de la localidad, propietario de una importante industria de mármol, con un capital social de 4.500.000 ptas; en Elda las nuevas campanas del templo fueron apadrinadas, entre otras autoridades, por el alcalde José Martínez González, procurador en cortes y propietario de Rodolfo Guarinos, industria del calzado con un capital social de más de 3.000 .000 ptas., mismo capital que Calzados Luvi de Petrer, propiedad de los hermanos Villaplana, con cargos en el ayuntamiento y en el sindicato de la piel. García y Navarro o Chico de Guzmán en Petrer, son nombres que también aparecen identificados a este proceso.

La confluencia de intereses entre el poder político, la Iglesia y los empresarios se manifestó plenamente en toda esta serie de reposiciones, en las que la invasión del espacio público, oficializado por la Iglesia, apareció como instrumento de socialización fundamental, produciéndose una clara confusión entre el carácter religioso y político de estas manifesta- 


\section{Violencia, legitimidad y poder local. La construcción simbólica de la dictadura franquista en una comarca alicantina. el Vinalopó Medio, 1939-1948}

ciones. Por otra parte, la integración simbólica que produjo toda esta serie de manifestaciones litúrgico-políticas se consiguió instrumentalizando las ideas religiosas de una parte de la población, a la vez que plasmaban la identidad de intereses de todos los grupos que apoyaron al régimen, que comulgaron con una misma visión del sistema político, social y económico, envuelto, eso sí, en un ambiente triunfalista de imposición de la moralidad católica, principal instrumento de legitimidad del régimen.

Como muestra de este ambiente provocado por la íntima colaboración de los distintos poderes locales en la construcción simbólica de la dictadura, quedan las palabras de un párroco de la época (nota 96). A riesgo de alargarme en exceso en las conclusiones valgan éstas como epílogo a lo dicho en este artículo:

"Precedidos de las autoridades civiles militares y judiciales, cuya presidencia de honor ocupaban el señor alcalde, señor comandante militar de la comandancia militar que se creo en Elda después de la liberación para custodia y depuración de estos pueblos; señor Juez militar; señor Juez municipal; señor sargento de la guardia civil; ayuntamiento; comisión pro-construcción de la nueva Imagen de nuestra Patrona; Milicias de la 


\section{Pedro Payá López}

Falange Española Tradicionaleiata y de las JONS y Organizaciones Juveniles, en sus secciones masculinas y femeninas, con sus jerarquías, banderas y bandas de tambores y cornetas; excombatientes y cautivos del periodo revolucionario que estuvieron encerrados en las cárceles de los rojos a disposición de la checas...nos dirigimos a la entrada del pueblo con la cruz parroquial alzada, y en la fábrica de Calzados "Luvi", propiedad de los hermanos Villaplana, donde se encuentra preparada y dispuesta al efecto, la Nueva Imagen de Nuestra Patrona la Virgen del Remedio.. por haber sido destruida por fuego, aquella venerada Imagen...al empezar el periodo revolucionario de dominación masónico-marxista que hemos atravesaso, cuando en julio de 1936 los revolucionarios rojos incendiaron el templo parroquial...llegados a dicho punto...las bandas de tambores y cornetas de la falange rompieron tocando la marcha real, para saludar en señal de júbilo y alegría a nuestra madre con los acordes del Himno Nacional".

En el mensaje no había sitio para el perdón sino para la venganza y el escarmiento, es decir, la violencia como elemento purificador: 
Violencia, legitimidad y poder local. La construcción simbólica de la dictadura franquista en una comarca alicantina. el Vinalopó Medio, 1939-1948

"Acto seguido, elevado sobre una silla dirigí la palabra al pueblo... les amonesté para que no se dejen llevar por esas fingidas voces de comprensión y convivencia con el fin de que no les cause alarma el aparente patriotismo de los rojos, que dicen querer a la Virgen del Remedio y queman, destruyen y saquean templos e imágenes...invité a nuestros caídos y a nuestros mártires a que desde los luceros se unan a nosotros y saluden a la Virgen...con el fin de que no sea inútil la sangre que derramaron por tan santa y noble causa; $y$ después de demostrar que las fiestas con que Petrel honra en el presente año a la Santísima Virgen del Remedio, son fiestas de la Victoria, a la vez que de honor, júbilo, alegría, amor, veneración, exaltación, reconocimiento, reparación y desagravio" (nota 97). 


\section{Pedro Payá López}

* Este trabajo ha sido posible gracias a la concesión de una beca de formación de personal investigador concedida por el Ministerio de Ciencia y Tecnología y que se inserta en un proyecto más amplio dirigido por el profesor Glicerio Sánchez Recio con referencia PB980984.

1. Aróstegul, Julio, "Violencia, sociedad y política: la definición de la violencia", Ayer, n. ${ }^{\circ}$ 13, 1994, pp. 17-55.

2. MIR, Conxita, "Violencia política, coacción legal y oposición interior", en SÁnCHEZ ReClo, Glicerio (ed.), El primer franquismo, Ayer, n. ${ }^{\circ}$ 33, 1999, pp. 115-145.

3. Ver entre otros AquARONE, Alberto, L'organizzacione dello stato totalitario. Milán, Eunadi, 1965; del mismo autor, "Violenza e consenso nel fascismo italiano", Storia Contemporánea, a. X, n. 1, febbraio 1979, pp. 145-155.

4. LYTTELTON, Adrian, "Fascismo e violenza: conflicto sociale e azione politica in Italia nel primo dopoguerra", Storia Contemporánea, a. XIII, n. 6, dicembre 1982, pp. 965-983; y GeNTILE, Emilio, II culto del littorio. La sacralizzazione della política nell'Italia fascista, Roma-Bari, Laterza, 1993.

5. Gentile, Emilio, "II fascismo come religione politica", Storia Contemporánea, a. XXI, n. 6, dicembre 1990, pp. 1079-1108. Un desarrollo de estas tesis la hace en I/ culto del Littorio... op. cit.

6. En este sentido es clarificador el estudio de SÁNCHEZ RECIO, Glicerio, De las dos ciudades a la Resurrección de España. 


\section{Violencia, legitimidad y poder local. La construcción simbólica de la dictadura franquista en una comarca alicantina. el Vinalopó Medio, 1939-1948}

Magisterio pastoral y pensamiento político de Enrique Pla y Deniel, Valladolid, Ámbito, 1995.

7. Sevillano Calero, Francisco, "Totalitarismo, fascismo y franquismo: el pasado y el fin de las certidumbres después del comunismo", en Moreno Fonseret, Roque y Sevillano Calero, Francisco (eds.), El franquismo. Visiones y balances, Alicante, 1999, pp. 13-26.

8. Sevillano Calero, Francisco, Propaganda y medios de comunicación en el franquismo, Alicante, 1998.

9. Principalmente estos son los grupos en los que se plasma y desarrolla lo que podemos definir como poder local, que no debemos identificar simplemente con administración local. La importancia de la historia local para establecer las relaciones y juegos que se dan entre los diversos poderes ha sido puesta de manifiesto por NicolÁs MARín, M" Encarna, "Los poderes locales y la consolidación de la dictadura franquista”, en SÁNCHEZ ReCIO, Glicerio (eds.), op. cit., pp. 6585.

10. Los empresarios más importantes de la comarca fueron nombrados alcaldes o concejales en estas localidades. Son los casos, por ejemplo, de Martínez González, Porta Rausa, Bellod Payá o Benéit Navarro en Elda; Tortosa Jiménez y Barberá Tordera en Monóvar o Santiago García y Manuel Villaplana en Petrer. Ver PAYÁ LóPEZ, Pedro, "Franquismo y poder local en la comarca del Vinalopó Medio. La formación del personal político franquista, 1939-1948”, en PAYÁ LóPEZ, Pedro (coord.), La implantación del franquismo en la comarca. 


\section{Pedro Payá López}

"Dossier" de la Revista del Vinalopó, n. 4, 2001, pp. 31-60. Para la provincia MORENo FonSERET, Roque, "Burguesía y nacionalsindicalismo. Control obrero, beneficio económico y poder político en la Organización Sindical Alicantina", Anales de la Universidad de Alicante. Historia Contemporánea, n. 8-9, 1991-92, pp. 191-214.

11. Sobre el desarrollo de la prensa en la provincia de Alicante ver Moreno SÁEZ, Francisco (ed.), La prensa en la provincia de Alicante durante la Segunda República, 1931-1936, Alicante, 1994.

12. Sobre la prensa durante el franquismo en la provincia de Alicante ver Sevillano Calero, Francisco, "Propaganda y opinión en Alicante durante el primer franquismo", en SánCHEz ReCio, Glicerio; Moreno Fonseret, Roque y SeVillano Calero, Francisco, Estudios sobre el franquismo en la provincia de Alicante. Poder político, actitudes económicas y opinión, Alicante, 1995, pp. 89-105.

13. SeVillano Calero, Francisco, "Propaganda i control de l'opinió en els inicis del franquisme: el cas de la provincia d'Alacant", Recerques. Història, Economia, Cultura, n. ${ }^{\circ}$ 39, 1999, pp. 55-72.

14. Archivo Municipal de Monóvar, (AMM), caja 20.

15. Sevillano Calero, Francisco, "Propaganda i control de l'opinió..." op. cit., p. 60.

16. Archivo Municipal de Mónovar (AMM), caja 20.

17. González Calleja ha señalado cómo "la criminalización de los individuos e instituciones leales a la República era la alternativa política más útil y socialmente más adecuada al ambiente de venganza 


\section{Violencia, legitimidad y poder local. La construcción simbólica de la dictadura franquista en una comarca alicantina. el Vinalopó Medio, 1939-1948}

que se respiraba, frente a la dificultosa fundamentacion legal de un régimen directamente emanado de un golpe de estado". Ver GonzÁlez Calleja, Eduardo, "Violencia política y represión en la España franquista. Consideraciones teóricas y estado de la cuestión", en Moreno Fonseret, Roque y Sevillano Calero, Francisco (eds.), op. cit., pp. 119-150.

18. Libros de plenos del ayuntamiento de Monóvar, actas de 1 de mayo y 15 de junio de 1939 .

19. Mauss, Marcel, Institución y culto: representaciones colectivas y diversidad de civilizaciones, Barcelona, 1971.

20. González Calleja, Eduardo, "Violencia política y represión en la España franquista...” op. cit., p. 124.

21. AMM, caja 20.

22. Sevillano Calero, Francisco, "Propaganda y opinión en Alicante..." op. cit., p. 91.

23. Valle de Elda, 30 de marzo de 1957.

24. Ver Payá LóPez, Pedro, "La implantación del franquismo en Elda. Poder local y actitudes políticas", Alborada, n. ${ }^{\circ} 44,2000$, pp. 47-58.

25. No es el caso del excelente artículo de Magdalena Calvo, J.I.; Escudero, Ma ${ }^{a}$ Carmen; Prieto Altamira, Alfredo y Reguillo, José, "Los Lugares de Memoria de la Guerra Civil en un centro de poder: Salamanca, 1936-39", en ARóstegul, Julio (coord.), Historia y memoria de la guerra civil española, Valladolid, 1988, Vol. II, pp. 487-549. Sobre los principales mitos del régimen franquista ver GoNZÁLEZ 


\section{Pedro Payá López}

Calleja, Eduardo y Limón Nevado, F., La hispanidad como instrumento de combate. Raza e Imperio en la prensa franquista durante la Guerra Civil, Madrid, 1988. Ver también JIMÉNEZ CAMPO, Javier, "Rasgos básicos de la ideología dominante entre 1939 y 1945", Revista de Estudios Políticos (Nueva Época), n. ${ }^{\circ} 15$, mayo-junio 1980, pp. 79-117.

26. Ver por ejemplo Archivo Municipal de Elda (AME), caja 241/43; Libros de plenos del ayuntamiento de Elda, acta de 9 de octubre de 1942, en la que el alcalde ordena desarrollar una campaña contra la blasfemia en la localidad.

27. Desde el Gobierno Civil se recordaba a la alcaldía que "la vigente legislación social no permite la existencia de sociedades recreativas, debiendo éstas cambiar el título como tales y convertirse en deportivas o culturales". Archivo Histórico Provincial de AlicanteGobierno Civil (AHPA-GC), Legajo EPAY1941, (PC).

\section{Ibidem.}

29. Sobre el Gobierno Civil en la provincia de Alicante ver SANZ ALBEROLA, Daniel, La implantación del franquismo en la provincia de Alicante. El papel del Gobierno Civil, Alicante, 2000.

30. AHPA-GC, el subrayado es nuestro.

31. AHPA-GC, Agradezco a Daniel Sanz Alberola su amabilidad al dejarme esta documentación.

32. AHPA-GC-EP, Legajo 927, carpeta 21. 


\section{Violencia, legitimidad y poder local. La construcción simbólica de la dictadura franquista en una comarca alicantina. el Vinalopó Medio, 1939-1948}

33. Libros de plenos del ayuntamiento de Monóvar, acta de 16 de diciembre de 1942.

34. Para las memorias municipales de Elda, Novelda y Monóvar, Archivo General de la Administración (AGA), Gobernación, cajas 2932, 2949 y 2950. El proceso puede seguirse también en los libros de plenos de los distintos ayuntamientos.

35. Un buen ejemplo de la importancia concedida a la conquista del territorio como medio en el que proyectar los principales mitos del dominio político puede verse para el fascismo italiano en BALZANI, Roberto, "La casa natale di Benito Mussolini", Contemporánea, 1998, anno 1, n. ${ }^{\circ}$ 1, pp. 69-96. Los mitos aparecen así formando parte como elementos fundamentales del paisaje, encaminado a la integración simbólica y a la legitimación del poder.

36. Una visión interesante del fenómeno anticlerical en la historia de España puede verse en Delgado RuIz, Manuel, "Anticlericalismo, espacio y poder. La destrucción de los rituales católicos, 1931-1939", Ayer, n. ${ }^{\circ} 27,1997$, pp. 149-180. El autor no discrimina en su análisis los factores inconscientes y simbólicos que actúan en el fenómeno anticlerical, prestando especial importancia a la concepción del espacio público para explicar los ataques contra las imágenes, "el espacio, eso que las sociedades organizan pero que a su vez las somete, es lo que aparece privilegiadamente en litigio en el conflicto anticlerical en España", y es que las expresiones del culto fuera del templo "implicaban algo así como incursiones hacia (romerías, peregrinaciones) o de (procesiones, vía crucis) lo sagrado más allá de sus santuarios y que implicaba traslaciones por espacios así socializa- 


\section{Pedro Payá López}

dos". Esta tesis las desarrolla en su libro Luces iconoclastas. Anticlericalismo, espacio y ritual en la España contemporánea, Barcelona, 2001.

37. Sobre esta cuestión ver MoReno SeCo, Mónica, "El conflicte inexistent. Església i Falange a Alacant, 1939-1945", en Les bases locals del franquisme al País Valencià, "dossier" de L'Avenç, n. ${ }^{\circ} 262$, octubre 2001, pp. 46-47.

38. Además, por supuesto, de la cruz. El régimen franquista devolvió la cruz, el más importante de los símbolos católicos, a las escuelas, algo que quedaba pendiente devolver desde el momento que fue prohibida por la República. Para Frances Lannon el hecho de prohibir los crucifijos en las escuelas fue la gota que colmó el baso del antirrepublicanismo católico. Dice Lannon "en su visión de las cosas (de los católicos), la República se había condenado desde su primer mes de existencia al permitir la quema de conventos de mayo del 31; había completado su condena con su ataque legislativo a la Iglesia; $y$, por último, la había sellado definitivamente con su prohibición del crucifijo en escuelas y oficinas." LANNON, Frances, Privilegio, persecución y profecía. La Iglesia católica en España. 1873-1975, Madrid, 1992, p. 248.

39. JimÉnez CAmpo, Javier, op. cit., p. 128.

40. Moreno Fonseret, Roque, "Economía y poder local en Alicante (1939-1948). La función restauradora del régimen”, en TuSELL, Javier y otros (ed.), El régimen de Franco (1936-1975), Madrid, 1993, Vol. 1, pp. 99-114. 


\section{Violencia, legitimidad y poder local. La construcción simbólica de la dictadura franquista en una comarca alicantina. el Vinalopó Medio, 1939-1948}

41. Hemos de entender la represión más allá de su aplicación directa sobre las víctimas y tener en cuenta toda una serie de posturas que derivaron de su presencia en la vida pública, es decir, los efectos no contables de la represión. Ver MIR, Conxita, Vivir es sobrevivir. Justicia orden y marginación en la Cataluña rural de posguerra, Lleida, 2000.

42. Aróstegul, Julio, op. cit. p. 54.

43. Sobre la celebración del 20-N en Alicante ver Moreno SeCo, Mónica, "La evolución de un rito político: el 20 de noviembre en Alicante durante el franquismo", en IV Encuentro de Investigadores del franquismo, Valencia, 1999, pp. 662-667.

44. Sevillano Calero, Francisco, "Propaganda i control de l'opinió..." op. cit., p. 66. Una descripción del traslado hecha en la época puede verse en Ros, Samuel y Bouthelier, Antonio, A hombros de la falange. De Alicante al Escorial. Madrid, 1940?. Citado por Moreno Seco, Mónica, supra.

45. Libros de Plenos del ayuntamiento de Elda, acta de 21 de noviembre de 1939.

46. Ver GeNTILE, Emilio, "II fascismo come religione politica", op. cit., p. 1093.

47. Ver JimÉnez CAMPO, Javier, "Integración simbólica en el primer franquismo", Revista de Estudios Políticos (Nuena Época), n. ${ }^{\circ} 14$, marzo-abril 1980, pp. 125-143. Lo deja claro este autor: "La religión esto es lo importante- ocupa el espacio que no pueden cubrir formu- 


\section{Pedro Payá López}

laciones integradoras más "modernizantes"; la religión es la ausencia del mito de la "nación", desprovisto de un arraigo sufuciente", p. 126.

48. Archivo Municipal de Petrer (AMP), caja 22.

49. Ver Sennet, R., La carne y la piedra. Madrid, 1987. Citado por Delgado Ruiz, Manuel, op. cit., p. 173

50. Libros de plenos del ayuntamiento de Elda, acta de 16 de agosto de 1940.

51. Agradezco a $M^{\underline{a}}$ del Carmen Rico su amabilidad al haberme facilitado esta documentación.

52. Ver Payá LóPEZ, Pedro, "Franquismo y poder local en la comarca del Vinalopó Medio..." op. cit., pp. 56-59.

53. Navarro Pastor, Alberto, Historia de Elda. Tomo III.

54. Libros de Plenos del ayuntamiento de Petrer, acta de 16 de abril de 1939.

55. AMP- Correspondencia de alcaldía, caja 20.

56. Acta de la comisión de recaudación de 10 de diciembre de 1940.

57. Así se decidió en un pleno municipal. Libros de plenos del ayuntamiento de Petrer, acta de 17 de junio de 1940.

58. AMP, Memoria de la Comisión Pro-Monumento a los Caídos. Petrel, Julio de 1942.

59. GeNTILE, Emilio, "Il fascismo come religione politica", op. cit., pp. 1089 y ss. 


\section{Violencia, legitimidad y poder local. La construcción simbólica de la dictadura franquista en una comarca alicantina. el Vinalopó Medio, 1939-1948}

60. DuRKHeIM, Emile, Las formas elementales de la vida religiosa, Madrid, 1982, p. 360.

61. Boudon, Raymond; Besnard, Philippe; Cherkaoul, Mohamed y LÉCUYER, Bernard-Pierre: Diccionario de Sociología, Barcelona, 1995. Ver la voz rito.

62. Gentile, Emilio, I/ culto del littorio... op. cit., p. 53. Citado por Moreno SeCo, Mónica, "La evolución de un rito político..." op. cit., p. 663.

63. Ibídem.

64. AME, caja 247.

65. MÁÑEZ IÑESTA, Fernado, "Monaguillos", en Festa, 1994. Se trata de las memorias de una serie de monaguillos de la Iglesia de San Bartolomé de Petrer a los que el autor entrevisto, sin embargo no cita fecha de entrevista.

66. Para la provincia de Alicante Moreno Fonseret, Roque, La autarquía en Alicante (1939-1952). Escasez de recursos y acumulación de beneficios, Alicante, Instituto de Cultura "Juan Gil-Albert", 1994. Para Cataluña, Molinero, Carme e YsÀs, Pere, "Patria justicia y pan". Nivell de vida $i$ condicions de traball a Catalunya. 1939-1951, Barcelona, Edicions de la Magrana, 1985.

67. Weber, Max, Economía y Sociedad, México, 1979.

68. Sánchez Recio, Glicerio, De las dos ciudades...op. cit., p. 96 y ss. 


\section{Pedro Payá López}

69. DavidS, N. Z., Society and Culture in Early Modern France, Londres, 1975, p. 186. Citado por LYTTELTON, Adrian, "Fascismo e violenza..." op. cit., p. 983.

70. Sánchez Recio, Glicerio, De las dos ciudades... op. cit.

71. Bоввіо, Norberto, Elogio de la templanza y otros escritos morales, Madrid, Temas de Hoy, 1997. Especialmente la parte III.

72. Ver MIR, Conxita, "Violencia política, coacción legal y oposición interior ..., op. cit., p. 119.

73. Pueden verse, entre otros, los trabajos de RuIz Rico, J.J., El papel político de la Iglesia católica en la España de Franco (1936-1971), Madrid, 1977; ÁlvAREZ Bolado, Alfonso, El experimento del nacionalcatolicismo 1939-1975, Madrid, 1976; TelLo LÁzARO, J.A., Ideología y política. La Iglesia católica española, 1936-1959, Zaragoza, 1984; LANNON, Frances, Privilegio, persecución y profecía. La Iglesia Católica en España. 1873-1975, Madrid, 1992; TuselL, Javier, Franco y los católicos. La política interior española etre 1945 y 1957, Madrid, 1984; y HeRMET, Guy, Los católicos en la España franquista, Madrid, 1985-1986.

74. Ver DuRKHeIM, Emile, Las formas elementales de la religiosadad... op. cit., p. 287.

75. Moreno Seco, Mónica, La quiebra de la Unidad. Nacional-catolicismo y Vaticano II en la diócesis de Orihuela-Alicante, 1939-1975, Alicante, 1999; Cenarro Lagunas, Ángela, Cruzados y camisas azules. Los orígenes del franquismo en Aragón, Zaragoza, 1997; 


\section{Violencia, legitimidad y poder local. La construcción simbólica de la dictadura franquista en una comarca alicantina. el Vinalopó Medio, 1939-1948}

Fernández Fernández, Gerardo, Religión y poder. Transición en la Iglesia española, León, 1999.

76. Rico Callado, Francisco Luis, La reforma de la predicación en la España del siglo XVIII. Memoria de licenciatura inédita, Universidad de Alicante, 1999.

77. Moreno Seco, Mónica, "Iglesia, obreros y empresarios en el Vinalopó”, en PAYÁ LóPEZ, Pedro (coord.), La implantación... op. cit., especialmente pp. 65-71. Incluso en diversas ocasiones se predicó en talleres y fábricas, como en Elda, p. 66.

78. Boletín Oficial del Obispado de Orihuela (BOOO), 1 de mayo de 1940. Agradezco a Mónica Moreno su amabilidad al facilitarme esta documentación.

79. Ibídem.

80. Ver por ejemplo Delgado Ruiz, Manuel, "Estella: Notas sobre el poder y la fiesta", Cuadernos de Etnología y Etnografía de Navarra, julio-diciembre, 1986, pp. 251-273.

81. Cenarro Lagunas, Ángela, Cruzados y camisas azules. Los oríenes del franquismo en Aragón, 1936-1945, Zaragoza, 1997, p. 282; Moreno SeCo, Mónica, supra, pp. 61-75. Aunque no referido al periodo franquista, un buen aporte metodológico en DeLGADO RuIz, Manuel, "Anticlericalismo, espacio y poder..." op. cit., p. 170.

82. MÁÑEZ InIESTA, F., op. cit., p. 81. Declaración de Ricardo Tomás.

83. Ibídem, p. 79. Declaración de Germán Sala. 


\section{Pedro Payá López}

84. Moros y Cristianos, revista de fiestas de Petrer, 1940.

85. Moreno SeCo, Mónica, Nacional-catolicismo y Vaticano II...op. cit, pp. 55-56.

86. Navarro Pastor, Alberto, op. cit., p. 9.

87. Libros de Plenos del ayuntamiento de Elda, acta de 15 de septiembre de 1939.

88. Ibidem, acta del 15 de marzo de 1940.

89. Ver las distintas aportaciones en Alborada, no 39, pp. 53-55. Ver también referencia al Acta de la reunión del Consejo Parroquial de Elda, por la que los empresarios zapateros se comprometían a pagar un impuesto especial para la reconstrucción del templo parroquial de Santa Ana, en Valero Escandell, J.R. y otros, Elda, 1832-1980. Industria del calzado y transformación social, Elda, 1982.

90. Libros de Plenos del ayuntamiento de Elda, Acta de 14 de febrero de 1949.

91. Libros de plenos del ayuntamiento de Petrer, actas de 19 de diciembre de 1940 y de 7 de agosto de 1942.

92. AMP, Memoria Pro-Reconstrucción Iglesia Parroquial y Casa Abadía de Petrer.

93. Libros de Plenos del ayuntamiento de Elda, acta de 24 de octubre de 1939; para Petrer, acta del día 3 de junio de 1940.

94. No podemos olvidar que la percepción cotidiana de ese espacio era visto de distinta forma por unos y otros, desde su posición de ven- 


\section{Violencia, legitimidad y poder local. La construcción simbólica de la dictadura franquista en una comarca alicantina. el Vinalopó Medio, 1939-1948}

cedores o vencidos. Pilar Folguera ha llamado la atención sobre esta importante diferenciación, "no puede describirse la vida cotidiana de la población como algo homogéneo, sino que necesariamente deben establecerse distinciones entre las diferentes clases sociales y las diferentes ideologías de sus componentes". Ver "La construcción de lo cotidiano durante los primeros años del franquismo", Ayer, ㄲo 19. 1995, pp. 165-187.

95. SÁnCHEZ ReCIO, Glicerio, Los cuadros políticos intermedios del régimen franquista, 1936-1959. Diversidad de origen e igualdad de intereses, Alicante, 1996, especialmente pp. 145-155.

96. Se trata del manuscrito que el párroco escribió en aquellos momentos, dejando constancia de los acontecimientos, con el título de Datos interesantes. Parroquial Iglesia de San Bartolomé. Apóstol de la Villa de Petrel. A partir de su estudio puede analizarse de forma extraordinaria, por la naturaleza de ser una fuente emanada desde la institución eclesiástica, no sólo la relación entre los distintos poderes de la época en la construcción de la dictadura, sino todo el universo simbólico y de mentalidades que se vivió, a partir de la figura del sacerdote.

97. He de dar las gracias al párroco de la Iglesia de San Bartolomé de Petrer, Don Antonio Rocamora Sánchez, por su amabilidad al dejarme consultar esta fuente. Creo de que su disposición es un ejemplo de custodia objetiva de los archivos, que tanta falta hace hoy día para el estudio del régimen de Franco. Por su excepcionalidad de nuevo mis más sincera gratitud. 